\title{
Relationship Workloads with Work Satisfactionlabor Contract on The Tomkins Shoes Company
}

\author{
R. Rina Novianty Ariawaty, Siti Noni Evita \\ Faculty of Economics and Business, Padjadjaran University, Bandung \\ Email: rina.novianty@unpad.ac.id
}

\section{A R T ICLE INFO}

Date of entry:

21 April 2020

Revision Date:

7 May 2020

Date Received:

10 May 2020

\begin{abstract}
A B S T R A C T
In facing global market competition, every company has different production standards. To meet work targets, the company imposes work on both low and high workloads. The workload was allegedly able to affect the satisfaction felt by the workforce. This study aims to determine the relationship of workload with contract labor satisfaction. The method used in this research uses the descriptive method by taking a sample of 86 contract workers. Analyze the correlation between variables, namely workload and job satisfaction, using the Spearman Rank Correlation formula. The results of this study indicate that there is a relationship between workload and job satisfaction of contract workers found that there is a relationship with a percentage of $21.6 \%$.
\end{abstract}

Keywords: Workload and Job Satisfaction

Cite this as: Ariawaty, R. R. N., Evita. S. N. (2020). Relationship Workloads with Work Satisfactionlabor Contract on The Tomkins Shoes Company. Jurnal Ilmu Manajemen Advantage. 4(1), 6-14. https://doi.org/10.30741/adv.v4i1.601

\section{INTRODUCTION}

PT. Primarindo Asia Infrastructure Tbk is one of the companies in Indonesia, which is engaged in the footwear manufacturing industry brand "TOMKINS," in which the company involves many workers to meet its production targets. The company is a labor-intensive industry, which means the company employs many people in carrying out its business activities. The total workforce owned by companies in conducting their business activities is 648 contract workers, where contract workers are workers who are directly related to shoemaking activities.

The activity of making shoes in having standard workmanship in a day is 400 pairs of shoes, in a work period of time in 5 days or a week can produce 2,000 pairs of shoes, which also means that in one-month contract labor can produce 40,000 pairs of shoes with a working period of 20 days. The yield per month is 40,000 pairs of shoes work standards of the company itself. The standard processing time is 8 hours per day. The observation found that a lot of work had not been carried out effectively and efficiently, which meant that it was not yet on target and on time. Furthermore, it is known that the distribution of workload is not consistent every month. Determination of 
workload adjusts to orders received by the company so that the workload received by employees fluctuates or differs each month.

The high workload felt by contract workers for almost a year can cause a decrease in job satisfaction. This decrease in job satisfaction can lead to an action where labor does not have the passion for doing work because job satisfaction is not fulfilled. In addition, indications of high workloads that can affect job satisfaction received by contract workers can be shown through the level of absenteeism in the company.

Job satisfaction at work is job satisfaction that is enjoyed at work by obtaining praise for work results, placement, treatment, equipment, and a good working environment. The company does not currently fulfill labor rights. This can be seen by not fulfilling safety equipment in the form of masks and special clothing because workers are required to come into contact with chemicals. The company also does not provide supplementary benefits such as uniforms, which in the end, the workers wear everyday clothes in carrying out their activities. In addition, the company does not provide food and transportation allowances. This study aims to determine the conditions of workload, satisfaction, and the relationship between workload and job satisfaction of contract workers at the TOMKINS Shoes Company.

Robbins (2007: 160) states that positive and negative workload is a matter of perception. Perception is defined as a process whereby individuals organize and interpret their sensory impressions to give meaning to their environment. Perceptions of workload are related to the role and work attribute factors. This is because the perception of workload is closely related to a job, where the individual provides an assessment of the number of task demands or activities that require mental and physical activities that he must complete within a certain time, whether it has a positive or negative impact on his work.

Workload according to Hart \& Staveland (Tarwaka 2011: 106) that workload is emerging from the interaction between the demands of work environment tasks, which are used as workplaces, skills, and perceptions of workers. Workloads are sometimes operationally defined on factors such as job demands or efforts made to do work. So the workload is one aspect that must be considered by every company.

A related study conducted by Hart (2006) also mentioned other methods for measuring multidimensional workloads that are relative and require time in working on a job. This method is a method known as the National Aeronautics and Space Administration Task Load method Index (NASA-TLX) (Hart and Staveland 1988). In NASA-TLX, there are six dimensions of workload size, namely: 1) Mental demand (mental needs), namely the demands of mental activity and per session needed in completing work. 2) Physical demand (physical needs) is the physical strength needed in completing work. 3)Temporal demand (time needed) that is the time needed to complete the work. 4) Performance (performance), namely success in completing work to achieve predetermined targets. 5) Effort (level of effort), namely the level of mental and physical strength expended to achieve the desired work.

National Aeronautics and Space Administration Task Load Index (NASA-TLX) Method using a 5 point Linkert scale measurement that moves from very unsatisfactory to very satisfactory levels. According to Robbins (2003: 91), the term job satisfaction refers to an individual's general attitude towards work that he does. Someone with a high level of job satisfaction shows a positive attitude towards work. Someone who is dissatisfied with his job will show a negative attitude towards the job. This employee attitude is called job satisfaction. Job satisfaction is basically something that is individual. Each individual has a different level of satisfaction in accordance with the rating system that is believed by him. The higher the rating system, the higher one's satisfaction, and vice versa. 
Job satisfaction is basically something that is individual. Each individual has a different level of satisfaction according to the assessment made by each individual. The higher the satisfaction felt by an employee, the happier he will be in doing his work. Dissatisfaction can be shown by lazy to go to work until lazy to do the work. This dissatisfaction can trigger the failure of the company's goals. A certain level of job satisfaction can prevent employees from finding work in other companies. An employee will feel comfortable and high loyalty to the company if you get job satisfaction in accordance with what is desired. Employees who have gained satisfaction from the company will have a sense of connection or more commitment to the company. On the other hand, satisfaction can also encourage employees to be better. Some instruments that can be used as a measurement of job satisfaction in general use questionnaire instruments, often also referred to as research on attitudes towards work. There are several advantages to using standardized instruments, namely the level of vanities and reliability.

The Minnesota Satisfaction Questionnaire (MSQ). The first job satisfaction measurement questionnaire was The Minnesota Satisfaction Questionnaire (MSQ), compiled by Weiss et al. in 1967. MSQ measures twenty aspects of job satisfaction and is a popular measurement. The eighteen aspects include1) Activities; 2) Independence; 3) Variations; 4) Moral Values; 5) Social Services; 6) Utilization of Capabilities; 7) Proficiency; 8) Responsibilities; 9) Creativity; 10) Recognition; 11) Achievements; 12) Social Status; 13) Relationship with Bosses; 14) Technical Ability; 15) Policy Authority; 16) Compensation; 17) Working Conditions; and 18) Colleagues.The Minnesota Satisfaction Questionnaire (MSQ), using a 5-point Linkert scale measurement that moves from very unsatisfactory to very satisfactory levels.

The dimensions of the dependent variable and the independent variable are obtained methods to identify the relationship between workload and job satisfaction. Where the independent variable is the workload variable, and the dependent variable is job satisfaction. Workload variable using the National Aeronautics and Space Administration Task Load Index (NASA-TLX) is a theory proposed by Hart and Staveland (1998), while the work satisfaction variable uses The Minnesota Satisfaction Questionnaire (MSQ) Weiss (1967). The use of these methods is used supported by studies from previous research that have been done, as well as looking at the problems of the company where the fluctuating workload is the point of job satisfaction. Low and high workloads will affect the form of satisfaction received by the company's workforce. An increase or decrease in job satisfaction can also be indicated to be influenced by the low or high level of workload that exists within the company.

The workload variable shows how much work and responsibility is assumed by the workforce. This workload variable will be linked to the job satisfaction variable where job satisfaction is shown to find out how much the level of job satisfaction relationships enjoyed or expected by the workforce towards the workload being worked on. Job satisfaction shows satisfaction in work and outside work.

The model of the relationship of workload with job satisfaction can be described as follows: 


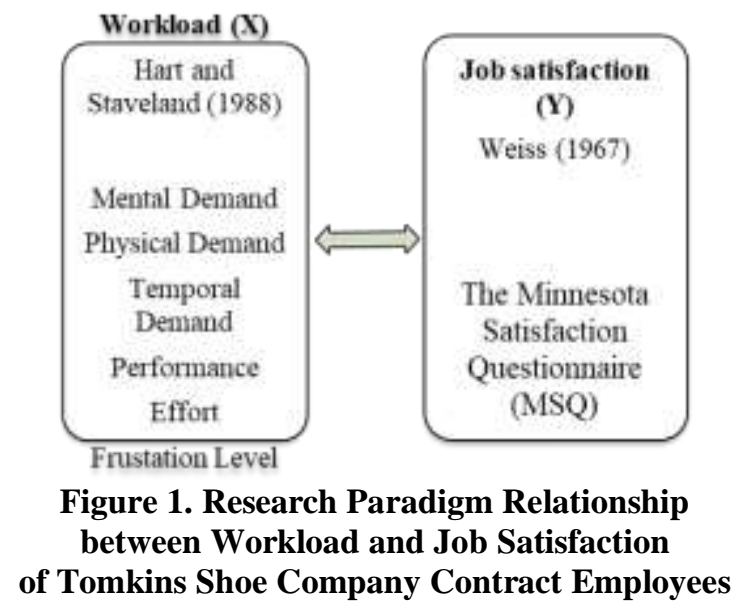

\section{METHODS}

The research method used in this study is a descriptive approach with quantitative methods with the aim to determine the relationship of workload with the satisfaction of contract labor at Tomkins Shoe Company. A. workload using the National Aeronautics and Space Administration Task Load Index (NASA-TLX) Method, which was first developed by Hart and Staveland (1988), wherein the NASA-TLX method there are six dimensions, namely: 1) Mental Demand; 2) Physical Demand; 3) Temporal Demand; 4) Performance; 5) Effort; and 6) Frustration Level. B. Job Satisfaction uses the theory of job satisfaction measurement The Minnesota Satisfaction Questionnaire (MSQ) according to Weiss (1968). The Minnesota Satisfaction Questionnaire (MSQ) measurement includes 18 indicators, namely: 1) Activities; 2) Independence; 3) Variations; 4) Moral Values; 5) Social Services; 6) Utilization of Capabilities; 7) Proficiency; 8) Responsibilities; 9) Creativity; 10) Recognition; 11) Achievements; 12) Social Status; 13) Relationship with Bosses; 14) Technical Ability; 15) Policy Authority; 16) Compensation; 17) Working Conditions; and 18) Colleagues. This study involved a sample of 86 respondents who were contract laborers PT. Primarindo Asia Infrastructure Tbk or TOMKINS Shoe Company. The data in this study were obtained by several data collection techniques including 1) Observation; 2) Questionnaire; 3) Interview; 4) Literature Study

Validity Testing is done on both variables, namely workload and job satisfaction. To test the validity of items, the Product Moment formula is used. The validity test results found that: 1) Workload variable, with the number of items as many as 25 items, shows that for the workload variable is valid with $0.635 \geq 0.3$; and 2) Job satisfaction variable, with the number of items as many as 21 items, shows that for the variable job satisfaction is declared valid with $0.696 \geq 0.3$.

Reliability testing is also carried out on both workload and job satisfaction variables. To test reliability is done by using Cronbach Alpha using SPSS. The reliability test results show that 1) Workload variable, a value of 0.646 was obtained $\geq 0,600$ so that it is declared reliable; and 2) Job satisfaction variable, obtained a value of $0.646 \geq 0,600$ so that it is declared reliable.

Further analysis for the classification and creation of data categories used data tabulation according to Redi Panju (1995: 147) as follows: 1) The minimum index value is the minimum score multiplied by the number of questions multiplied by the number of respondents. 2) The maximum index value is the highest score multiplied by the number of questions multiplied by the number of respondents. 3) The interval is the difference between the maximum index value and the minimum index value. 4) Interval distance is the interval divided by the number of levels desired. In this study, a bivariate statistical test using the Spearman Rank correlation analysis 
method. Spearman correlation coefficient is a nonparametric statistic. Spearman coefficient test is used to see the strength of the relationship between two variables that have an ordinal measurement scale, which is to see the relationship strength between the independent variable (Workload) and the dependent variable (Job Satisfaction).

\section{RESULTS AND DISCUSSION}

The characteristic analysis was carried out to obtain an overview of individual data including, age, last education, years of service, and gender of the respondent. Research on the characteristics of respondents based on several categories was conducted to obtain an overview of the identity of respondents. The total number of samples used was 86 or $n=86$.

The characteristic analysis found that: 1) Age of Respondents found that, ages 36 to 40 years, in general, are productive ages for contract workers to get good work results; 2) Last Education Respondents found that high school education levels can meet the needs of companies that rely on skills and accuracy rather than the ability to think; 3) working period. Respondents found that a work period of 16 to 20 years can show that workers who work for companies can be said to have long worked at the company and said to be skilled, and 4) Gender of Respondents in which the dominance of the female sex can be said that companies prefer to make women worse because they are considered more thorough.

The implementation of work activities in the company is determined by how much the job order is received. This job order is a point of how much workload will be received by the workforce later. This workload is also supported by workers who directly produce products using physical and mental strength they possess, even though there is a machine, but only as an auxiliary tool so that the products produced are more optimal. Respondents responded to the questions in the questionnaire, with the average answer being quite agreed and agree. This can be indicated that indeed the workload received by the workforce is high, and the workforce is also required to complete all work that is charged.

Respondent Answer Scores for Workload : Min Value $=1$ x 25 x $86=2.150$, Max Value $=5$ x 25 x $86=10.750$, Range Data $=10.750-2.150=8.600$, Class Width $=8.600: 5=1.720$. Respondent's Score $=8.434$, Maximum Score $=10.750$, Minimum Score $=2.150$, Percentage $=$ $8434 / 10750 \times 100 \%=78.46 \%$.

\begin{tabular}{llc}
\multicolumn{1}{c}{ Table 1. Scale } & \multicolumn{1}{c}{ Results } \\
\hline Percentage Scale & \multicolumn{1}{c}{ Information } & \\
$26 \%-25 \%$ & Uncomfortable & $78.46 \%$ \\
$51 \%-75 \%$ & Comfortable enough & Very comfortable \\
$76 \%-100 \%$ & Comfortable & \\
\hline
\end{tabular}

\begin{tabular}{lrrrrr} 
Light & \multicolumn{2}{c}{ A bit heavy } & Quite heavy & $\begin{array}{c}\text { Weight } \\
(8434)\end{array}$ & Very heavy \\
\hline 2150 & 3870 & 5590 & 7310 & 9030 & 10750
\end{tabular}


Table 2. The workload of Tomkins Shoe Company Contract Workers

\begin{tabular}{lrrl}
\hline Dimension & $\begin{array}{c}\text { Respondent } \\
\text { Answer Score }\end{array}$ & $\begin{array}{c}\text { Percentage of } \\
\text { Respondents' } \\
\text { Answers }\end{array}$ & $\begin{array}{c}\text { Conditions of } \\
\text { Respondents }\end{array}$ \\
\hline Mental Demand & 1509 & $87.73 \%$ & Very comfortable \\
Physical Demand & 1464 & $85.12 \%$ & Very comfortable \\
Temporal Demand & 1267 & $73.66 \%$ & Comfortable \\
Performance & 1607 & $74.74 \%$ & Comfortable \\
Effort & 1465 & $85.17 \%$ & Very comfortable \\
Frustration Level & 1122 & $65.23 \%$ & Comfortable \\
Total & 8434 & $78.46 \%$ & Very comfortable \\
\hline
\end{tabular}

Source: Data Processing Results (2017)

Based on the above table, it can be seen that the condition of the workload of contract labor in the Tomkins Shoe Company generated respondents' answers score from the six dimensions of workload amounted to 8434, that respondents perceive the conditions of workloads imposed on their work are heavy workloads. But with this large workload, $78.46 \%$ revealed that the workforce felt comfortable with the workload they received. This can show that with work targets that exceed the workload standards set by the company, the workforce feels that the workload is felt heavy, but the workforce can still do the work well.

Job satisfaction is a form of feeling comfortable or uncomfortable workers in carrying out business activities. Job satisfaction can affect workforce performance. Job satisfaction can encourage a form of support to make the workforce better at work. The calculation results obtained form of satisfaction that occurs in the company as follows: Respondent Answer Score for Job Satisfaction : Min Value $=1 \times 21 \times 86=1806$, Max Value $=5 \times 21$ × $86=9030$, Range Data $=9030-1806=$ 7224, Class Width $=7224: 5=1444,8$. Respondent's score $=5896$, Maximum Score $=9030$, Minimum Score $=1806$, Percentage $=5896 / 9030 \times 100 \%=65.29 \%$

Table 3. Job Satisfaction of Contract Employees of the Tomkins Shoe Company

\begin{tabular}{lrcr}
\hline \multicolumn{1}{c}{ Indicator } & $\begin{array}{c}\text { Respondent } \\
\text { Answer Score }\end{array}$ & $\begin{array}{c}\text { The scale of } \\
\text { Respondents' Answers }\end{array}$ & $\begin{array}{c}\text { Percentage of } \\
\text { Respondents' Answers }\end{array}$ \\
\hline Activity & 310 & Satisfied & $72.09 \%$ \\
Independence & 366 & Very satisfied & $85.12 \%$ \\
Variation & 228 & Quite satisfied & $53.02 \%$ \\
Moral values & 302 & Satisfied & $70.23 \%$ \\
Social services & 278 & Quite satisfied & $64.65 \%$ \\
Utilization of & 255 & Quite satisfied & $59.3 \%$ \\
Capabilities & & & \\
Finesse & 315 & Satisfied & $73.26 \%$ \\
Responsible & 331 & Satisfied & $76.98 \%$ \\
Creativity & 223 & Not satisfied & $51.86 \%$ \\
Recognition & 190 & Not satisfied & $44.19 \%$ \\
Achievement & 252 & Quite satisfied & $58.61 \%$ \\
Social status & 271 & Quite satisfied & $63.02 \%$ \\
Relationship with & 331 & Satisfied & $76.98 \%$ \\
Bosses & & & $64.65 \%$ \\
Technical Ability & 278 & Quite satisfied & $47.67 \%$ \\
Policy Authority & 205 & Not satisfied & $51.46 \%$ \\
Compensation & 442 & Not satisfied & $75.12 \%$ \\
Working conditions & 646 & Satisfied & $78.20 \%$ \\
Co-workers & 673 & Satisfied & $65.29 \%$ \\
\hline Total & 5.896 & & \\
Source: Data Processing Results $(2017)$ & &
\end{tabular}




\begin{tabular}{ccccc}
$\begin{array}{c}\text { Very } \\
\text { Dissatisfied }\end{array}$ & $\begin{array}{c}\text { Not } \\
\text { Satisfied }\end{array}$ & $\begin{array}{c}\text { Quite satisfied } \\
(5896)\end{array}$ & Satisfied & $\begin{array}{c}\text { Very } \\
\text { Satisfied }\end{array}$ \\
\hline 1806 & 3250,8 & 4695,6 & 6140.4 & 7585.2
\end{tabular}

Based on the above table, it can be seen that the job satisfaction of contract workers at Tomkins Shoe Company generated job satisfaction by involving 18 indicators of job satisfaction. The respondent's answer score was 5896 that respondents perceived job satisfaction received by workers in the moderately satisfied category. Job satisfaction in the quite satisfied categorization is felt by as much as $65.29 \%$ of the workforce.

Testing the relationship between workload and job satisfaction of contract workers at the Tomkins Shoe Company was carried out using Spearman's statistical motedo. The confidence interval rate used is $95 \%$ (significance level $\alpha=0.05$ ) where Ho is rejected if ${ }^{Z_{\text {hitung }}}$ > or, in other words, the relationship between the two variables, namely workload and job satisfaction is significant. In the correlation test to find the value of the correlation coefficient located in the interval $-1 \leq \mathrm{r} \leq 1$.

Table 4. Workload Correlation with Job Satisfaction

\begin{tabular}{llrr}
\hline & Workload & Job Satisfaction \\
\hline Workload & Pearson Correlation & 1 & 0,216 \\
& Sig. (2-tailed) & & 0,045 \\
& $\mathrm{~N}$ & 86 & 86 \\
Job Satisfaction & 0,216 & 1 \\
& Pearson Correlation & 0,045 & 86 \\
& Sig. (2-tailed) & 86 & \\
& $\mathrm{~N}$ & & \\
\hline
\end{tabular}

Source: Data Processing Results (2017)

Based on calculations using SPSS from the table above, it can be seen that the Spearman correlation coefficient number between workload variables $(\mathrm{x})$ and job satisfaction variables $(\mathrm{y})$ is +0.216 , which can be concluded that the workload variable with the job satisfaction variable found a positive relationship that indicates there is a relationship between two variables. At the same time, the coefficient figures from the table show a rather weak correlation between workload and job satisfaction of $21.6 \%$.

\section{CONCLUSION}

The condition of the workload of contract workers at the Tomkins Shoe Company can be perceived to be the condition of the workload felt by contact labor is very convenient. The categorization of workloads is included in heavy workloads. Job satisfaction of Tomkins Shoes Company contract workers can be perceived that the satisfaction of workloads is in a sufficiently satisfying position where it can be said that the company has not been able to fulfill all the workforce satisfaction of contract workers. The workload with job satisfaction Tomkins Shoe Company contract labor has a positive relationship, which means it shows the relationship between workload and job satisfaction with the strength of the relationship is rather weak. This is because the satisfaction caused by workload does not cause job satisfaction directly to the workforce. Given the indicator.

Suggestion, Workloads that must be considered by the Tomkins Shoe Company are: Activities related to the dimensions of mental demand, physical demand, and effort should be more attention to the skills, work equipment, and comfort of workers in carrying out work activities because activities related to these dimensions require a high form of energy that must also be supported by facilities by the company which is expected to be a form of encouragement for workers to work better. While activities related to temporal demand, performance, and frustration level required a 
form of encouragement provided by the company to provide comfort and workload that can be well received by workers because although time needs can be met by workers, fatigue is felt by labor can reduce performance and cause frustration in the workforce.

Job satisfaction must be considered by the Tomkins Shoe Company, namely: Low relationship on job satisfaction as perceived by four indicators including, creativity, recognition, policy authority, compensation. The four indicators show that there is dissatisfaction. Companies can listen more to the suggestions expressed by the workforce for indicators of creativity in which labor will not feel constrained by what he thinks. Meanwhile, the recognition and authority of company policy can enhance equality and fairness in all forms of facilities provided to contract workers. Indicators of compensation, the company can calculate retribution with the work target being enforced. Moderate relationship on job satisfaction as perceived by six indicators, including variations, social service, ability utilization, achievement, social status, technical ability. These six indicators can be facilitated by the company in the presence of a seminar or training that can be received by the workforce that will be useful in future work activities.

\section{REFERENCE}

Soeprijadhie, A. J.P. (2013). Factors of Job Satisfaction Effect on Employee Performance on the radio Republic of Indonesia Manado. E-EMBA Journal. Vol 1 No.4 Pg. 60-68. ISSN 2303-1174

Dessler, G. (2010). Human Resource Management, Volume 1 and Volume 2. Jakarta: PT Prenhallindo.

Triashening, F. I. (2003). Measuring Employee Motivation and Job Satisfaction using Job Diagnostic Survey Method and Minnesota Satisfaction Questionaire.

Hanapi, L. K. (2013). Measuring Workload with NASA Method-TALK Load Index on the CV. Gimera Jaya Bandung . E-Journal of Industrial Engineering, Dian Nuswantoro University

Sahin, H., Sahingoz, S. R. (2013). The Relationship between Personnel Workload and Work Satisfaction within Accommodation and Nutrition Establisments. Journal of America International journal of Social Science. Vol 2 No.3

Handoko. (1996). Personnel Management and Human Resources. Edition 2. Yogyakarta: BPFE Publisher.

Malayu, H. S. P. (2005). Human Resource Management: Basis and Keys to Success. Jakarta: Masagung

Herzberg, F. (2000). Fundamentals of Management. Translated by Malayu SP Hasibuan. Second Edition. Jakarta: Earth Literacy.

Kreitner, R and Kinicki. (2008). Organizational Behavior. 8th Edition. Boston: McGraw-Hill

MENPAN. (1997). Definition of Workload http://www.bkn.go.id accessed at 24 March 2017

Munandar, S. A. (2001). Industrial Psychology. Jakarta: University of Indonesia Publishers

Mustapha, Noorani. (2013). Examining Faculty as Antecendent of Job Satisfaction among Academic Staff of Higher Public Education in Kelantan, Malaysia. Journal of Business and Management Horizon: ISSN 2326-0297. Vol 1 No.1

Robbins, S. P. (1999). Organizational Behavior: Concepts, Controversies and Applications. New Jersey: Prentice Hall.

Sabrini, A. et al. (2013). Measurement of Employee Workload with Using the SWAT Method (Subjective Workload Assessment Technique) and Work Sampling at PT. XYZ USU's Industrial Engineering E-Journal. Vol.8 No.2. ISSN 2443-0579

Setyono A. et al. (2007). Analysis of Factors That Affect Job Stress and Its Effect on Satisfaction. University e-journal Diponegoro. Vol. 4 No.3

Sudjana. (1997). Statistics Method. Bandung: Tarsito

Sugiyono. (2007). Quantitative, Qualitative and R\&D Research Methods. Bandung: Alfabeta

Silalahi, U. (2009). Social Research Methods. Bandung: Refika Aditama 
Syeed, S. H. S., et al. (2011). Workload and Performance of Employees". Interdisciplinary Journal of Contemporary Research in Business

Thomas, E. N, et al. (1998). Individual Differences in Perceived Importance of SWAT Workload Dimension: Effect on Judgment and Performance in a Virtual High Workload Environment.

Umar, H. (1997). Research Methodology. Jakarta: PT Gramedia Pustaka Utama 